\title{
SOCIAL COMMUNICATIONS PROMLEMS IN THE CONTEXT OF THE E-LEARNING FORMATION AND DEVELOPMENT
}

УДК 378.4+004.75

DOI https://doi.org/10.32843/2663-

5208.2019.9.11

\section{Жовнір A.O.}

аспірантка кафедри прикладної соціології та соціальних комунікацій

Харківський національний університет імені В.Н. Каразіна

\begin{abstract}
У статті розкриваються особливості електронних комунікацій в умовах інституту освіти. Розглянуто ключові виклики і транссоормації, які викликані стрімким розвитком інфрормаційно-комп'ютерних технологій. Окреслено можливі сценарії і наслідки фрормування нового комунікативного середовища в контексті віртуалізації комунікативних прочесів. Виділено ключові складові компоненти електронного комунікативного простору сучасного ЗВО. Акцентовано увагу на становленні і розвитку електронної освіти, а також на характеристиках інтернет-комунікацій. у статті представлені основні тенденції та транссоормації, що зумовлені створенням та формуванням епохи електронних комунікацій. Сьогодні ми стикаємося $з$ основними ризиками та загрозами, які пов'язані з активним розвитком інтернет-комунікацій. Насамперед йдеться про проблему інфрормаційної нерівності, соціальної ізоляції, проблеми соціалізації, комунікаційних бар'єрів, ідентичності тощо. Розвиток електронної освіти ініціює появу нових комунікативних моделей, комунікативного простору, учасників комунікативного прочесу. Сучасна система освіти повинна бути орієнтована на те, щоб перетворити студента з пасивного слухача на активного та ініціативного учасника навчального процесу, який володіє критичним та аналітичним мисленням, навичками пошуку творчих підходів до вирішення проблем, прагненням до постійного саморозвитку та самоосвіти. Щоб відповідати всім тенденціям на ринку праці, система освіти повинна запроваджувати інноваційні фоорми освіти, активно використовувати інфрормаційні та комп'ютерні технології, шукати есрективні моделі комунікації між учасниками освітньої діяльності. Ключові слова: соціальні комунікації, електронні комунікації, електронна освіта, інтернет-комунікації, інфрормаційно-комунікативний простір.
\end{abstract}

The article deals with the features of electronic communications in the conditions of the education institute. The key challenges and transformations, which are caused by the rapid information and computer technologies development, are considered. The possible scenarios and consequences of the new communicative space formation in the context of communicative processes virtualization are outlined. The key components of the electronic communicative space of the modern university are highlighted. Attention is focused on the formation and development of e-learning, as well as on the characteristics of Internet communications. The article presents the key trends and transformations that are caused by the creation and formation of the electronic communications era. Today we are faced with key risks and threats that are associated with the active development of Internet communications. First of all, we are talking about the problem of information inequality, social exclusion, the problems of socialization, communication barriers, identity etc. The development of e-learning initiates the emergence of new communicative models, communicative space, participants in the communicative process. The modern education system should be focused on turning a student from a passive listener into an active and enterprising participant in the educational process, possessing critical and analytical thinking, skills in finding creative approaches to solving problems, a desire for continuous self-development and self-education.

The education system, in order to meet all the trends in the labor market, should introduce educational innovative forms, actively use information and computer technologies, and look for effective communication models between participants in educational activities.

Key words: social communications, electronic communications, e-learning, Internet communications, information and communication space.
Постановка проблеми. Проблематика соціальних комунікацій все більш пронизуе усі сфери суспільної діяльності, що призводить не тільки до її популяризації в науковому дискурсі, але й до вирішення пов'язаних із цим онтологічних питань, зокрема, сьогодні на порядку денному стають значущими такі ключові теми: трансформація комунікативних моделей, формування нових соціальних груп, проблематика комунікативних бар'єрів тощо. Стрімкий розвиток комунікативних технологій та їх проникнення в усі сфери суспільної діяльності сьогодні змушує провідні соціальні інститути шукати нові стратегії розвитку та функціонування, які були б в змозі відповідати мінливим викликам сучасності. Всеохоплюючі тенденції інформатизації не в змозі були оминути один з головних та значущих інститутів, а саме - інститут освіти, та стати одними з ключових факторів його значних трансформацій та змін. У другій половині XX ст. з'являються різні соціологічні теорії та концепції, які наголошували на становленні якісно нової епохи - інформаційно-комунікативної, вимоги якої будуть виступати каталізатором модернізації освітньої системи в цілому.

Аналіз останніх досліджень і публікацій. Слід сказати, що проблематика соціаль- 
них комунікацій є науковим інтересом таких вчених, як Г. Лассуел, К. Шеннон, В. Вевер, Р. Якобсон, Т. Ньоком, Ю. Лотман, Ф. де Соссюр, Ч. Пірс, С. Бейкер, та інших. Серед вітчизняних вчених варто виділити наукові праці Г. Почепцова, В. Королько, В. Мойсеєва, О. Берегової, В. Різуна, Н. Зражевської та інших.

Постановка завдання. Метою цієї статті $€$ виділення та окреслення ключових особливостей соціальних комунікацій в умовах розвитку інформаційно-комунікативних технологій.

Виклад основного матеріалу. Сьогодні говорять про настання електронної епохи соціальних комунікацій як альтернативи усталеній традиційній системі. Найвідомішим дослідником початку епохи електронної комунікації вважають М. Маклюена, який проголосив завершення «ери Гутенберга» - книжково-документальної комунікації. В контексті проблематики формування електронної освіти насамперед ми говоримо про ті трансформаційні процеси, які відбуваються з соціальними комунікаціями у сфері освіти. Говорячи про електронну освіту, ми говоримо про циркуляцію символів та знаків в якісно іншому просторі, віртуальному. Отже, трансформаційні зміни системи соціальних комунікацій зумовлені глобальними процесами технологізації, інтернаціоналізації, індивідуалізації, гуманізації, віртуалізації освіти в цілому.

Під впливом інформатизації та розвитку соціальних комунікацій кардинально змінюються уявлення про сучасний заклад вищої освіти (ЗВО), метою діяльності якого стає не тільки вироблення, збір, зберігання і поширення знань, а й надання до них доступу незалежно від місцезнаходження користувача [1].

Новизна Інтернету як комунікаційного середовища полягає в тому, що він дає можливість кожному індивідуальному джерелу інформації окремої особистості, організації, корпорації сформулювати повідомлення і запропонувати його необмеженій кількості потенційних одержувачів. Об'єднання користувачів в мережі Інтернет призвело до створення якісно нового соціального простору, де різними способами можлива комунікація і інтеракція партнерів, які розділені простором, що належать до різних соціальних середовищ і систем, але здатні вступити у відносини в рамках нової комунікативної системи, що склалася. Інтернет ініціює зміни соціальної структури суспільства, створюючи нові спільноти, об'єднані за новими ознаками, серед яких комунікації стають все більш цілеспрямованими та інтенсивними, з одного боку, та може стати ключовим каталізатором соціальних нерівностей та поляризації соціальних груп - 3 іншого.

Мова як основний засіб спілкування людей теж зазнає змін, вона стає все більш алгорит- мізованою, відбувається мінімізація змісту понять і їх спрощення, що призводить до значної швидкості обробки і накопичення інформації. Крім того, сьогодні ми говоримо про формування особливого інтернет-сленгу, «нової» мови, яка стає універсальною, в тому числі для учасників освітнього процесу. Розвиток інтернет-комунікації впливає на традиційні форми письмової та усної комунікації, а отже, стає фактором впливу на культуру міжособистісного спілкування в цілому. Найбільш показовими є такі процеси: стає можливим говорити стисло та відмовитись від традиційних правил листування та обміну інформацією [3].

Соціальні комунікації сьогодні $€$ двоскладовими явищами, які об'єднують соціальний і комунікативний підходи. Взаємодія суб'єктів соціальних комунікацій в медіа-реальності відображає нову якість інформаційних суб'єктно-об'єктних відносин, яка пов'язана зі значним збільшенням активності медіа та прийняттям ними деяких соціомоделюючих функцій. Так, наприклад, А.М. Фортунатов у своїй роботі «Взаємодія суб'єктів соціальної комунікації в медіа-реальності» називає наступні основні характеристики сучасних комунікативних процесів: маніпуляцію, перформативність і медіатизацію [2].

Ті лінійні біхевіористичні моделі комунікації, які були тривалий час популярні (моделі Д. Лассуелла, Т. Ньюкомба), втратили свою актуальність в контексті віртуалізації освітнього простору. Комунікаційні процеси в ЗВО вимагають розробки більш складних моделей спілкування та обміну інформацією. Необхідно враховувати вплив соціальних інститутів, шляхів розповсюдження повідомлень, розрізняти рівні їх взаємодії. Комунікаційні моделі повинні передбачати наявність зворотних зв'язків із користувачами та комунікаційні бар'єри під час спілкування, обміну та передачі інформації між учасниками комунікації. У сучасних дослідженнях все ширше застосовуються системні моделі комунікації, які включають інформаційні процеси в більш широкий соціальний контекст.

Сучасні тенденції гуманізації свідчать про те, що ми йдемо від традиційної моделі передачі інформації та відтворення знань вчителя та засвоєння їх учнями. В контексті електронної освіти ми маємо справу з інтерактивною «партнерською» моделлю, яка перестає розглядати учня як пасивного реципієнта. Він стає агентом освітнього процесу, який активно координує комунікативну діяльність. В цьому виражається індивідуалізація освіти, у зв'язку з чим змінюються методики навчання, комунікації повинні мати особистісний характер, що може забезпечити система електронної освіти. В результаті формування нового комунікативного середовища трансформується 
такожй ідентичність учасників комунікативного процесу, сьогодні трансформується система соціальних статусів і ролей. Ми відмовляємось від споживання дихотомії «вчитель-учень» і від їх традиційних поведінкових рис, ми говоримо про т'ютора, який лише наставляє учня, допомагає йому знайти необхідну інформацію та обробляти її самостійно.

На основі вивчення основних компонентів комунікації та особливостей соціальної комунікації, зумовленої розвитком нових інформаційно-комунікативних технологій, комунікацію сучасного навчального закладу слід розглядати як комунікацію, яка $є$ опосередкованою навчальним документом, в тому числі і електронним, побудованою на обміні цими документами, які формують документальні потоки, що рухаються по комунікаційним каналами під час комунікаційного процесу.

Основними складниками інформаційно-комунікативного середовища ЗВО є: суб'єкти комунікації (студенти та професорсько-викладацький склад), засоби комунікації (інструменти та технології, канал передачі); предмет комунікації та повідомлення; ефекти комунікації (наслідки комунікаційної діяльності проявляються або в поведінці, або у внутрішньому стані або у відносинах суб'єктів цього спілкування). Але передусім в електронній освіті з'являється посередник - інформаційно-комунікативні технології, ті засоби та канали, від яких залежить не тільки ефективність, але й сама можливість реалізації комунікативного процесу [4].

Отже, які ми можемо виділити особливості електронних комунікацій?

1) віртуальність (віртуальний простір);

2) опосередкованість;

3) інтерактивність;

4) гіпертекстуальність (численні одночасні потоки інформації);

5) глобальність (долає просторово-часові обмеження);

6) креативність;

7) можливість анонімної комунікації;

8) мозаїчність;

9) деперсоніфікованість (маємо справу з символами та знаками);

10) загальнодоступність;

11) можливість зберігання результатів комунікації (електронна пам'ять);

12) інтегрованість;

13) оперативність (динамічність) комунікації;

14) ускладненість емоційного компонента спілкування [4].

Анонімність електронних комунікацій надає можливість приховати риси реального «Я», такі як стать, вік, зовнішність, освіту, соціальний статус, і використовувати замість них ті, що наближені до ідеального «я» особистості.
Отже, ми відзначаємо віртуальну комунікацію не просто між персонами, соціальними масками, а між «ідеальними» персонами, які стають на захист власної ідентичності.

Популяризація концепцій безперервної освіти ("life-long-learning") призвела до того, що ми відчули потребу в методах і технологіях організації комунікації, які здатні були б забезпечувати особистісний та професійний розвиток протягом усього життя. Безперервна електронна освіта, яка не $€$ обмеженою ні часовими, ні просторовими обмеженнями.

Крім того, електронну освіту визначають як поетапну комунікацію, спрямовану на накопичення, трансформацію і розвиток вже наявних навичок, умінь, емоційних реакцій, а також практик діяльності. 3 точки зору соціально-культурного конструктивізму освітній процес є комунікативною соціально-культурною діяльністю, головним призначенням якої $€$ організація ефективної взаємодії та діалогу між суб'єктами навчання. Цей підхід натякає на те, що для організації ефективного навчального процесу необхідно поєднувати електронний навчальний контент (технології самоосвіти) і традиційні методи навчання. Під час виконання цих умов буде досягнуто формування соціально-конструктивістського досвіду, який буде оптимізувати і підвищувати ефективність навчального процесу [1].

Поєднання вербальної та невербальної інформації (картинка, звуковий фрагмент тощо) також є типовим для деяких жанрів електронної комунікації. Комунікація між користувачами мережі здійснюється засобами природної мови, яка в Інтернеті отримує ряд додаткових функцій. Можна сміливо стверджувати, що електронний дискурс багато в чому $€$ новим типом і якісно іншим простором комунікації. Значною мірою це пов'язано з частковим зняттям етичних бар'єрів комунікації, що зумовлено віртуальним середовищем. Сьогодні ми спостерігаємо, що комп'ютерний сленг переходять в загальновживану лексику і діловий дискурс, та стають все більш популярними ігрові умови комунікації, навіть у діловій сфері.

Однак, говорячи про електронну комунікацію, слід наголосити на виникаючих комунікативних бар'єрах, особливо в процесі віртуальної міжкультурної комунікації - в розбіжності когнітивних просторів комунікантів, джерелом якої є використання різних моделей сприйняття дійсності, що неминуче знаходить відображення в електронному дискурсі.

У контексті електронної освіти ми можемо спостерігати міжособистісну, масову (one-tomany or many-to-many) та автомасову, синхронні та асинхронні комунікації (у цьому контексті ми говоримо про роботизацію, у зв'язку з якою стає можливою двостороння комунікація з автоматизованими системами). 
Висновки. Резюмуючи, слід наголосити на тому, що сьогодні, у зв'язку з технологізацією освітнього процесу, кардинально змінюється інформаційно-комунікативна функція освіти, яка раніше мала на меті не тільки передачу та трансляцію знань, але й морально-етичне виховання, соціалізацію, культурний розвиток тощо. Але, на жаль, сьогодні усі ці латентні, але такі важливі питання все більше втрачають свою значущість, що здійснює вплив на підготовку нового «цифрового» покоління.

\section{ЛITEРАTУРА:}

1. Жулкевська В.О. Дистанційна освіта: історичний аспект зарубіжного досвіду. Вісник Львівського університету. 2004. Вип. 18. С. 81-88.
2. Ибрагимова С.Н., Жельская Л.Б. Особенности современной Интернет-коммуникации. В мире науки и искусства: вопросы ффилологии, искусствоведения и культурологии: сб. ст. по матер. VII междунар. науч.-практ. конфр. Новосибирск, 2012.

3. Куликова А.В. Особенности интернет-коммуникаций. Вестник Нижегородского университета им. Н.И. Лобачевского. Серия «Социальные науки». 2012. № 4 (28). С. 19-24.

4. Кириченко Е.А., Ярута А.Г. Особенности Интернет-коммуникации как новой формы социализации в современном обществе. Межкультурная коммуникация: лингвистический, социальный и медицинский аспекты: сборник материалов Международной научно-практической консреренции. Курск, 2012. С. $17-21$. 